\title{
Suction sampling as a significant source of error in molecular analysis of predator diets
}

\author{
R.A. King ${ }^{1, *}{ }^{\dagger}$, J.S. Davey ${ }^{1}$, J.R. Bell ${ }^{1,2}$, D.S. Read $^{1 \ddagger}$, \\ D.A. Bohan ${ }^{2 \S}$ and W.O.C. Symondson ${ }^{1}$
}

${ }^{1}$ Cardiff School of Biosciences, Biomedical Sciences Building, Cardiff University, Museum Avenue, Cardiff, CF10 3AX, UK: ${ }^{2}$ Plant and Invertebrate Ecology, Rothamsted Research, West Common, Harpenden, Hertfordshire, AL5 2JQ, UK

\begin{abstract}
The molecular detection of predation is a fast growing field, allowing highly specific and sensitive detection of prey DNA within the gut contents or faeces of a predator. Like all molecular methods, this technique is prone to potential sources of error that can result in both false positive and false negative results. Here, we test the hypothesis that the use of suction samplers to collect predators from the field for later molecular analysis of predation will lead to high numbers of false positive results. We show that, contrary to previous published work, the use of suction samplers resulted in previously starved predators testing positive for aphid and collembolan DNA, either as a results of ectopic contamination or active predation in the collecting cup/ bag. The contradictory evidence for false positive results, across different sampling protocols, sampling devices and different predator-prey systems, highlights the need for experimentation prior to mass field collections of predators to find techniques that minimise the risk of false positives.
\end{abstract}

Keywords: aphid, carabid, Collembola, false positive, spider

(Accepted 8 September 2011; First published online 1 November 2011)

\section{Introduction}

Understanding the dynamics of invertebrate predator-prey interactions in their natural environment can be challenging. Within arable systems, knowledge of the links between pest

*Author for correspondence

Fax: + 44 (0) 1392263434

E-mail: R.A.King@exeter.ac.uk

tCurrent address: College of Life and Environmental Sciences, Geoffrey Pope Building, University of Exeter Stocker Road, Exeter, EX4 4QD, UK

$\ddagger$ Current address: Centre for Ecology \& Hydrology, Maclean Building, Benson Lane, Crowmarsh Gifford, Wallingford, OX10 8BB, UK

§Current address: UMR BGA - INRA Centre de Dijon, 17 rue Sully, BP 86510, 21065 Dijon Cedex, France species and their predators is fundamental for understanding species interactions and food webs. Traditional methods for analysing predation, such as microscopic identification of prey remains or direct observation of predation, are of little use for identifying trophic links in natural environments, particularly for small invertebrates, which are often nocturnally active fluid feeders. The application of molecular markers to elucidating predation has been a fast growing field (Symondson, 2002; King et al., 2008) and allows detection of predation with high sensitivity and specificity.

However, like all molecular methods, the molecular detection of predation is prone to potential sources of error, giving rise to both false positive and false negative results. Four main sources of error have so far been investigated. Using PCR-based methods, it is not possible to distinguish active predation from scavenging on dead prey. Both Foltan et al. (2005) and Juen \& Traugott (2005) showed that DNA from decaying prey was readily detected in predator guts. 
Secondary predation is also a possible source of error. Sheppard et al. (2005) showed that it was possible to detect aphid DNA in carabid beetles that had fed on spiders that had been digesting aphid DNA for up to $4 \mathrm{~h}$. Additionally, soil dwelling invertebrates living in close proximity to their food sources may become surface contaminated with DNA from that food source (Remén et al., 2010). These three sources of error can potentially lead to false positive results. DNA extracted from predator gut contents or faecal samples can often contain PCR inhibitors (Hebert et al., 2011), and this can lead to false negatives (Juen \& Traugott, 2006). The now routine screening of predator DNA extracts with general or species specific PCR primers and using PCR facilitators such as bovine serum albumin (Juen \& Traugott, 2005, 2007) has largely eliminated this source of false negatives.

King et al. (2008) also suggested that field methods that either confine the sample in a small area (e.g. dry pitfall traps, sweepnets, malaise traps) or cause the animal to regurgitate its stomach contents through submersion in a killing solution (e.g. wet pitfall traps, hand collecting into ethanol), could also lead to false positive results. Small predators are effectively collected using suction sampling (Sunderland et al., 2005), providing measures of density and potentially a source of predators for gut content analysis. These samplers take the form of either a portable G-vac (modified garden blowers, less commonly Dietrick (D-vac) samplers) that use a net or sock to collect the sample, or a Vortis machine that uses centrifugal force (Wheater et al., 2011). As the predators and target prey combine in the collecting cup or bag, two potential sources of false positives may occur. It is possible that because of the impact of the high-speed collection methods, small, fragile invertebrates such as aphids and collembola become squashed and then ectopically contaminate predators with their DNA. Additionally, due to containment in the enclosed environment of the collecting cup or bag, predation could be 'forced', allowing individual predators to forage freely on captured prey, especially immediately after the machine has been turned off. Such predation could potentially inflate the number of predators testing positive and lead to trophic links that do not occur naturally in the field. It was suggested that low vortis/vacuum pressures and transferring predator immediately onto ice, could mitigate these problems (King et al., 2008).

Recent studies have investigated the potential for predator collection methods to give rise to false positive results. Harwood (2008) and Chapman et al. (2010) compared hand collection of spider predators with sweep-netting and Vortis sampling, respectively. In both studies, no significant differences were found between the proportions of hand collected versus sweep-netting/vacuum collected spiders testing positive for Diptera protein (Harwood, 2008) or aphid and collembolan DNA (Chapman et al., 2010), suggesting that these alternative sampling methods were suitable for the collection of predators for molecular analyses. Conversely, Greenstone et al. (2010) found moderate levels of false positives in predators (pentamid bugs and chrysomelid beetles) collected using both rough (predators beaten from plants onto cloth and collected using a pooter) and hand collection methods. They suggested that the difference between their results, and those of Harwood (2008) and Chapman et al. (2010), could be due to differences in predator biology.

Here, we test the hypothesis that suction sampling of predators for molecular analyses leads to high levels of false positive trophic links. We designed a set of complementary experiments using field-based techniques and starved spider and beetle predators (hence, two very different feeding modes and biology). The predators were screened by PCR for the presence of multiple prey, revealing trophic errors that are most likely to occur in studies that use suction samplers.

\section{Materials and methods}

Predators were collected from the field and then starved for seven days prior to the start of the experiments, to ensure their guts were empty. They were marked with acrylic paint to identify starved from any non-starved predators that might be simultaneously collected from the field during the experiments. Both experiments were conducted in winter wheat fields.

\section{Field methods - experiment 1}

Using a Vortis sampler (Burkhard Ltd, Rickmansworth, UK), 20 aphids (Sitobion avenae) per sample ( $n=12$ samples) were sucked from a plastic disc into the Vortis along with one Tachyporus hypnorum (Staphylinidae), one Bembidion lampros and one Demetrias atricapillus (both Carabidae). A further nine sucks of three seconds each was performed across a winter wheat field, replicating a standard protocol (overall, ten sucks each lasting three seconds, equating to a sampling area of $0.6 \mathrm{~m}^{2}$ : Bell et al., 2010). At this point, in each replicate sample, the D. atricapillus was removed from the collection pot, placed in an individual $1.5 \mathrm{ml}$ microcentrifuge tube and frozen at $-80^{\circ} \mathrm{C}$ (a priori removal). A starved Notiophilus biguttatus (Carabidae) was then added (post-hoc addition) to the sample before all of the contents were transferred into a plastic bag. Bags were placed in an insulated box with ice packs (temperature approximately $5^{\circ} \mathrm{C}$ ) in the field and then transferred to an incubator with no light and set at $10^{\circ} \mathrm{C}$. Predators were killed in absolute ethanol after $1 \mathrm{~h}$ and $24 \mathrm{~h}$ (six replicates each). The removal of $D$. atricapillus was used to assess whether DNA from squashed aphids or collembola could coat the beetles' exoskeleton. The post-hoc addition of $N$. bigutattus was used to assess whether false positives could be caused by predation in the collection cup, independent of the effect of the Vortis. Positive results for T. hypnorum or B. lampros could be due to either ectopic contamination or post-collection predation.

\section{Field methods - experiment 2}

Using a converted Electrolux McCulloch BVM 250 leafsucker with a muslin collection sock, starved spiders (four each of Bathyphantes gracilis, Tenuiphantes tenuis (both Linyphiinae), Pachygnatha degeeri (Tetragnathiidae) and Erigone spp. (Erigoninae)) were released and immediately sucked directly from the soil surface $(15 \mathrm{~s}$ suck at full power over an area of $0.5 \mathrm{~m}^{2}$ : Davey, 2010). The leafsucker was switched to low power to position it over a $10 \times 10 \times 30 \mathrm{~cm}$ plastic box $25 \%$ full of dry ice. The surface temperature of dry ice is approx $-75^{\circ} \mathrm{C}$ and, therefore, sufficiently cold to kill specimens almost immediately, precluding feeding at this stage. The leafsucker was turned off, and the contents of the collection sock were immediately emptied into the box containing dry ice. The experiment was performed twice, once at the field margin and once $10 \mathrm{~m}$ into the field. In both experiments, in addition to the starved predators, many other 
Table 1. PCR primers used in this study.

\begin{tabular}{|c|c|c|c|c|c|c|}
\hline Prey species & $\begin{array}{l}\text { Primer } \\
\text { name }\end{array}$ & Primer sequence $\left(5^{\prime}-3^{\prime}\right)$ & $\begin{array}{l}\text { Fragment } \\
\text { size }\end{array}$ & Ta & Reference & Experiment \\
\hline General & LCO1490 & GGTCAACAAATCATAAAGATATTGG & $710 \mathrm{bp}$ & $47^{\circ} \mathrm{C}$ & Folmer et al., 1994 & $1 \& 2$ \\
\hline Invertebrate & $\mathrm{HCO} 2198$ & TAAACTTCAGGGTGACCAAAAAATCA & & & & \\
\hline Collembola spp. & $\begin{array}{l}\text { Col4F } \\
\text { Col5R }\end{array}$ & $\begin{array}{l}\text { GCTACAGCCTGAACAWTWG } \\
\text { TCTTGGCAAATGCTTTCGCAGTA }\end{array}$ & $177 \mathrm{bp}$ & $57^{\circ} \mathrm{C}$ & $\begin{array}{l}\text { Kuusk \& Agustí, } \\
2008\end{array}$ & $1 \& 2$ \\
\hline
\end{tabular}

Table 2. Results of Experiment 1 using beetle predators. $A$ ' + ' and ' - ' indicate that a predator tested either positive or negative, respectively for a particular prey. An ' $x$ ' indicates that a predator was not present in the Vortis collection cup.

\begin{tabular}{|c|c|c|c|c|c|c|c|c|}
\hline Replicate & \multicolumn{2}{|c|}{ Demetrias atricapillus ${ }^{\mathrm{a}}$} & \multicolumn{2}{|c|}{ Bembidion lampros } & \multicolumn{2}{|c|}{ Notiophilus biguttatus } & \multicolumn{2}{|c|}{ Tachyporus hypnorum } \\
\hline 1.1 & - & - & - & + & - & - & + & - \\
\hline 1.3 & + & - & $x$ & $x$ & - & - & $x$ & $x$ \\
\hline 1.4 & - & + & + & + & + & + & $x$ & $x$ \\
\hline 1.5 & - & - & - & - & + & + & + & - \\
\hline 24.2 & + & - & - & + & - & - & - & + \\
\hline 24.3 & - & + & - & - & - & + & $x$ & $x$ \\
\hline 24.4 & - & - & - & - & - & - & - & - \\
\hline 24.5 & + & - & + & + & - & + & - & + \\
\hline 24.6 & - & - & - & + & - & + & - & - \\
\hline
\end{tabular}

a -Demetrias atricapillus was removed from all replicates and killed prior to storage in an incubator. For clarity, results for this species are still presented with the replicate from which they were removed.

invertebrates (including Diptera, Collembola, Coleoptera, Hemiptera, Arachnida), soil, grit and wheat straw were sucked from the soil.

\section{Molecular methods}

Genomic DNA was extracted using DNeasy Tissue Kits (Qiagen, Crawley, UK) following the manufacturers instructions. Predators (except D. atricapillus from experiment 1 ) were partially crushed in $200 \mu$ l of extraction buffer $(180 \mu$ l Buffer ATL and $20 \mu \mathrm{l}$ Proteinase $\mathrm{K}$, both Qiagen) prior to the 2-h incubation stage. DNA was extracted from $D$. atricapillus without prior crushing (the aim was to test for topical contamination). To check for potential cross contamination of samples during DNA extraction, each batch of extractions included a negative control (a 'blank sample' extracted using the same protocol as invertebrate samples: King et al., 2008).

All samples were initially screened with the universal primers LCO1490 and HCO2198 (Folmer et al., 1994) that amplify a $710 \mathrm{bp}$ fragment of the mitochondrial cytochrome oxidase subunit I (COI) gene. This was to check for successful extraction of amplifiable DNA. Predators were screened for prey DNA using the primers listed in table 1 . PCR reactions were carried out in a total volume of $25 \mu \mathrm{l}$, consisting of $1 \times$ PCR master mix (Invitrogen, Paisley, UK), $4 \mathrm{mM} \mathrm{MgCl}_{2}$ (Invitrogen), $0.05 \mathrm{mM} \mathrm{dNTP}$ mix (Invitrogen), $2.5 \mu \mathrm{g} \mathrm{BSA}$ (bovine serum albumin, New England Biolabs, Hitchen, UK), $0.1 \mu \mathrm{M}$ each forward and reverse primer, $0.625 \mathrm{U}$ Taq polymerase (Invitrogen) and $2.5 \mu \mathrm{l}$ DNA. After an initial denaturing step at $94^{\circ} \mathrm{C}$ for $2 \mathrm{~min} 30 \mathrm{~s}$, amplification proceeded for 35 cycles at $94^{\circ} \mathrm{C}$ for $30 \mathrm{~s}$, annealing temperature (table 1) for $30 \mathrm{~s}$,

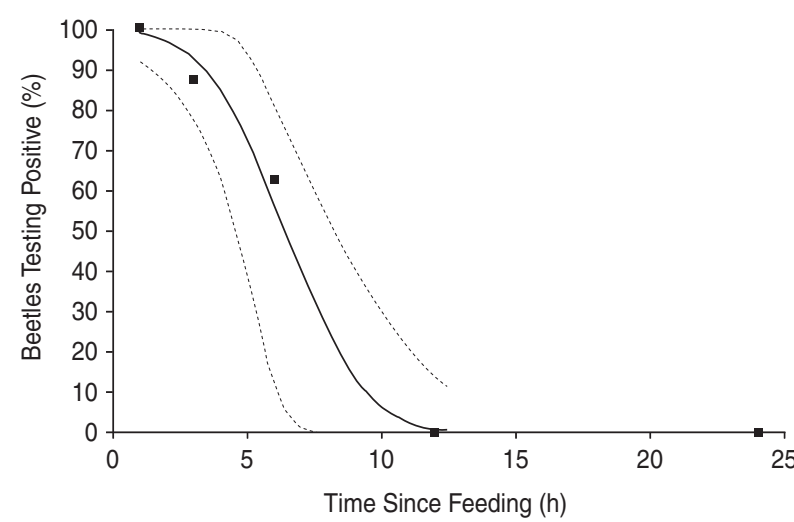

Fig. 1. Detectability of collembolan DNA in the gut of Notiophilus biguttatus. ., PCR data. Lines are fitted probit models with 95\% confidence intervals. The median detection time (the time at which $50 \%$ of beetles test positive) is $6.39 \mathrm{~h}$.

$72^{\circ} \mathrm{C}$ for $45 \mathrm{~s}$ and a final extension at $72^{\circ} \mathrm{C}$ for $10 \mathrm{~min}$. PCRs were carried out in a MJ Research PTC200 thermal cycler (Bio-Rad, Hemel Hempstead, UK). PCRs were visualised on $1.5 \%(\mathrm{w} / \mathrm{v})$ agarose gels stained with ethidium bromide.

\section{Controlled feeding trial}

To ensure that the starvation period was sufficient to empty the guts of the predators used in the above experiments, 
Table 3. Results of Experiment 2 using spider predators, showing recapture rates and numbers of predators testing positive for collembolan DNA

\begin{tabular}{llccc}
\hline Predator species & Experiment & $\mathrm{N}_{\text {spiders }}$ & $\mathrm{N}_{\text {recaptured }}$ & $\begin{array}{c}\text { Spiders positive } \\
\text { for Collembola } \\
\text { spp. DNA }\end{array}$ \\
\hline Bathyphantes gracilis & Margin & 4 & 1 & 0 \\
Tenuiphantes tenuis & In field & 4 & 3 & 0 \\
& Margin & 4 & 3 & 0 \\
Pachygnatha degeeri & In field & 4 & 4 & 4 \\
Erigone spp. & Margin & 4 & 4 & 3 \\
& In field & 4 & 3 & - \\
\hline
\end{tabular}

the detection limit for the Collembola spp. primers (Kuusk \& Agustí, 2008) was determined using a controlled feeding trial with $N$. biguttatus as the predators. Adult N. biguttatus were collected from the soil surface in arable fields using an electric pooter and maintained under controlled conditions $\left(16^{\circ} \mathrm{C}\right.$ and a 16:8 L:D cycle) with access to water but no food. After seven days of starvation, beetles were placed individually in $5 \mathrm{~cm} \varnothing$ Petri dishes with three adult Folsomia candida. After $2 \mathrm{~h}$, beetles that had consumed all three $F$. candida were removed and placed individually into clean Petri dishes. Beetles were killed at $-80^{\circ} \mathrm{C}$ at set times post-feeding period $(1,3,6,12$ and $24 \mathrm{~h}$ after the mid-point of the feeding period). DNA was extracted from crushed whole beetles using the PureGene Tissue Extraction Kit (Gentra, Minneapolis, MN, USA). All beetles were screened for the presence of collembolan DNA using primers Col4F and Col5R (Kuusk \& Agustí, 2008).

\section{Data analysis}

For experiment 1, the proportions of each predator (excluding D. atricapillus) testing positive for aphid or collembolan DNA were modelled as a binomial generalized linear model whilst accounting for differences between prey species and time periods using Genstat 13th Edition (VSN international Ltd). For the Notiophilus/Isotoma feeding trial, the median detection time (equivalent to the detectability halflife of Chen et al. (2000)), i.e. the time at which $50 \%$ of beetles still tested positive for collembolan DNA, was determined using Probit analysis performed in MINITAB v 15 (Minitab Inc., 2008).

\section{Results}

\section{Field experiment 1}

Of the 48 predators used in this experiment, five (two B. lampros and three T. hypnorum; table 2) were not recovered from the collection pot in the Vortis suction sampler. Of the 12 D. atricapillus removed immediately after Vortis sampling, four $(33 \%)$ tested positive for aphid DNA and two (17\%) for collembolan DNA, indicating high rates of topical contamination.

Of the $12 \mathrm{~N}$. biguttatus added after completion of Vortis sampling, three (25\%) tested positive for aphids and six (50\%) for collembola, demonstrating high rates of predation within the sample bags during storage. The median detection time for the $N$. biguttatus fed with $F$. candida in the feeding trial was $6.39 \mathrm{~h}$ (fig. 1). No beetles tested positive in either the $12 \mathrm{~h}$ or
$24 \mathrm{~h}$ post-feeding time periods, showing that the starvation period was sufficient to ensure that beetles could not have had detectable collembolan DNA within their guts at the time the experiments were carried out.

A combination of contamination and/or predation was shown through analysis of the other two predators, $T$. hypnorum and B. lampros, both of which showed positives for aphid and collembolan DNA (table 2). Two B. lampros and three $N$. biguttatus tested positive for both aphid and collembola at the same time. However, no significant difference was found between the proportion of predators testing positive for collembolan and aphid DNA $(t=0.68$, $P=0.52$ ), between the proportion of predators testing positive at $1 \mathrm{~h}$ and $24 \mathrm{~h}(t=-0.51, P=0.63)$ or any differences in overall prey DNA detection between $B$. lampros compared and either $N$. biguttatus $(t=-0.40, P=0.70)$ or $T$. hypnorum $(t=-0.48$, $P=0.64)$.

\section{Field experiment 2}

Nineteen of the 32 starved spiders used in this experiment were recovered. No individuals of B. gracilis and Erigone spp. tested positive for the presence of collembolan DNA (table 3). However, despite using a methodology that did everything possible to prevent post-vacuum sampling predation, four $T$. tenuis and five $P$. degeeri tested positive for collembolan DNA (table 3).

\section{Discussion}

Contrary to the conclusions of Chapman et al. (2010), the results from these two experiments show that suction sampling has the potential to give rise to high numbers of false positive results. This could lead to inflation of the number of predators scored as positive for a particular prey species and/or a misrepresentation of the prey spectrum of specific predators. It is recommended that appropriate experiments, similar to those conducted here and by Chapman et al. (2010) and Greenstone et al. (2011), be conducted in order to determine the field sampling methods that best minimise the rates of false positive results in all analyses of the molecular detection of predation.

In experiment 1 , six D. atricapillus tested positive for aphid and collembolan DNA. As individuals of this species were placed immediately in ethanol after Vortis sampling and were not crushed during DNA extraction, the positive results were almost certainly due to ecotopic contamination of aphid and collembolan DNA on the beetles' exoskeleton. Greenstone 
et al. (2011) found that a high proportion of Podisus maculiventris and Coleomegilla maculata, deliberately surface contaminated with DNA of Leptinotarsa juncta, tested positive for this species. However, if these beetles did manage to eat target prey within this very short window of opportunity (a few seconds) then we cannot entirely rule out detection of gut contents, as demonstrated by Pons (2006) who were able to extract prey DNA from entire tiger beetles. Individuals of $N$. biguttatus also tested positive for predation on both aphids and collembola. As this predator species was added after the end of the vortis period, these positive results can only be due to active predation post vortising. The positive results for $B$. lampros and T. hypnorum could be due to either ectopic contamination or in-cup predation. In experiment 2, despite being killed immediately after collection, nine spiders tested positive for collembolan DNA (table 3 ). As with B. lampros and T. hypnorum from experiment 1 , this shows that either the spiders were contaminated ectopically with DNA from squashed collembola or that they were able to predate collembola within the collection sock of the modified leafsucker. Given the methodology employed in experiment 2 , the latter seems unlikely.

The results for the 24-h time period for experiment 1 would suggest that, even at the low temperatures within the incubator, the beetle species are still able to capture and consume prey. Kruse et al. (2008) have shown that temperature has a marked effect both on activity patterns and prey capture ability of Calathus fuscipes and Poecilus versicolor. These beetles had very low activity patterns at low temperature, but were able to capture Drosophila at temperatures below $10^{\circ} \mathrm{C}$. Alternatively, it is possible that the beetles could still be testing positive after having eaten prey before being put at low temperature. It has been shown that the temperature at which controlled feeding trials are carried out has an effect on the median detection time of prey DNA within the predator's gut (Hoogendoorn \& Heimpel, 2001; Davey, 2010). Mean detection rates of $S$. avenae DNA in the gut of Pterostichus melanarius were significantly higher in feeding trials conducted at $12^{\circ} \mathrm{C}$ and $16^{\circ} \mathrm{C}$ compared to one performed at $20^{\circ} \mathrm{C}$ (von Berg et al., 2008). For Folsomia candida fed the nematode Phasmarhabditis hermaphrodita, Read (2007) found that lowering the temperature at which the feeding trial was conducted resulted in both an increase in median detection time $\left(22.18 \mathrm{~h}\right.$ at $24^{\circ} \mathrm{C}$ and $36.83 \mathrm{~h}$ at $4^{\circ} \mathrm{C}$ ) and a lengthening of the maximum detection time ( $36 \mathrm{~h}$ at $24^{\circ} \mathrm{C}$ and $48 \mathrm{~h}$ at $\left.4^{\circ} \mathrm{C}\right)$.

The results of experiment 2 show that, despite the short time between sample collection and placing the invertebrates on dry ice, some of the spiders were able to predate collembola within the collection sock. If the positive results were due to ectopic contamination with haemolymph from collembola damaged during suction sampling, we might expect positive results from all four species. Although sample numbers per species were too low to test for differences between spider species, the results potentially serve to highlight the opportunistic nature of predation in the case of both web-dependent ( $T$. tenuis) and itinerant ( $P$. degeeri) predators, even where precautions have been taken to minimise its occurrence.

In conclusion, the results of these experiments clearly show that mass sampling, using either Vortis samplers or converted leaf blowers, can lead to both contamination and/or unwanted predation within the equipment. Because food webs seem to be often characterised by many weak and few strong trophic links (Wooton \& Emmerson, 2005), these sources of false predation have the potential to undermine predictive models of food web function. Experiments must be done prior to mass field collections of predators to find the method that best minimises the risk of false positive results. Some prey, such as aphids and collembola, may be relatively fragile and more likely to break up and contaminate predators externally. Where this is likely, gentler methods, such as hand sampling or using low pressure suction samplers, may be preferable for obtaining samples for DNA analyses. These techniques may underestimate the density of some species (Bell et al., 2002); and, therefore, vacuum sampling can be used, in parallel, to estimate population densities. Other prey, such as the Aphrodes leafhoppers in the study by Virant-Doberlet et al. (2011), are hard-bodied and survive vacuum sampling intact. In the latter study, some common spider species caught using a modified leaf blower never tested positive for Aphrodes DNA, while other spider species caught at the same time showed high rates of predation; if contamination were an issue, all species would have been contaminated. Such 'internal' controls can, thus, provide a useful way of monitoring for such problems and should be checked at an early stage before major fieldwork is undertaken.

\section{Acknowledgements}

We are grateful to Gwenaëlle Fournier and Fleur MoirotCrouvisier for help in the field and to Rothamsted Research farm staff and Slade Farm, Glamorgan for accommodating our experiments. This work was part of a project entitled 'Dynamic responses of predators to biodiversity in sustainable agriculture: spatial and molecular analyses' funded by the Biotechnology and Biological Sciences Research Council (BBSRC grant BBD0011881). We thank two anonymous reviewers and the Subject Editor for providing valuable comments on an earlier draft of this manuscript.

\section{References}

Bell, J.R., Wheater, C.P., Henderson, R. \& Cullen, W.R. (2002) Testing the efficiency of suction samplers (G-vacs) on spiders. The effects of increasing nozzle size and suction time. pp. 285-290 in Toft, S. \& Scharff, N. (Eds) European Arachnology 2000. Århus, Denmark, Aarhus University Press.

Bell, J.R., King, R.A., Bohan, D.A. \& Symondson, W.O.C. (2010) Spatial co-occurrence networks coupled with molecular analysis of trophic links reveal the spatial dynamics and feeding histories of polyphagous predators. Ecography 33, 64-72.

Chapman, E.G., Romero, S.A. \& Harwood, J.D. (2010) Maximizing collection and minimizing risk: does vacuum suction sampling increase the likelihood for misinterpretation of food web connections? Molecular Ecology Resources 10, 1023-1033.

Chen, Y., Giles, K.L., Payton, M.E. \& Greenstone, M.H. (2000) Identifying key cereal aphid predators by molecular gut analysis. Molecular Ecology 9, 1887-1898.

Davey, J.S. (2010) Intraguild predation among generalist predators in winter wheat. $\mathrm{PhD}$ thesis, University of Cardiff, Cardiff, UK.

Folmer, O., Black, M., Hoeh, W., Lutz, R. \& Vrijenhoek, R. (1994) DNA primers for the amplification of mitochondrial 
cytochrome $\mathrm{c}$ oxidase subunit I from diverse metazoan invertebrates. Molecular Marine Biology and Biotechnology 3, 294-299.

Foltan, P., Sheppard, S., Konvicka, M. \& Symondson, W.O.C. (2005) The significance of facultative scavenging in generalist predator nutrition: detecting decayed prey in the guts of predators using PCR. Molecular Ecology 14, 4147-4158.

Greenstone, M.H., Weber, D.C., Coudron, T.C. \& Payton, M.E. (2011) Unnecessary roughness? Testing the hypothesis that predators destined for molecular gut-content analysis must be hand-collected to avoid cross-contamination. Molecular Ecology Resources 11, 286-293.

Harwood, J.D. (2008) Are sweep net sampling and pitfall trapping compatible with molecular analysis of predation? Environmental Entomology 37, 990-995.

Hebert, L., Darden, S.K., Pedersen, B.V. \& Dabelsteen, T. (2011) Increased DNA amplification success of non-invasive genetic samples by successful removal of inhibitors from faecal samples collected in the field. Conservation Genetics Resources 3, 41-43.

Hoogendoorn, M. \& Heimpel, G.E. (2001) PCR-based gut content analysis of insect predators: using ribosomal ITS-1 fragments from prey to estimate predation frequency. Molecular Ecology 10, 2059-2067.

Juen, A. \& Traugott, M. (2005) Detecting predation and scavenging by DNA gut-content analysis: a case study using a soil insect predator-prey system. Oecologia 142, 344-352.

Juen, A. \& Traugott, M. (2006) Amplification facilitators and multiplex PCR: tools to overcome PCR-inhibition in DNAgut-content analysis of soil-living invertebrates. Soil Biology and Biochemistry 38, 1872-1879.

Juen, A. \& Traugott, M. (2007) Revealing species-specific trophic links in soil food webs: molecular identification of scarab predators. Molecular Ecology 16, 1545-1557.

King, R.A., Read, D.S., Traugott, M. \& Symondson, W.O.C. (2008) Molecular analysis of predation: a review of best practice for DNA-based approaches. Molecular Ecology 17, 947-963.

King, R.A., Moreno-Ripoll, R., Agustí, N., Shayler, S.P., Bell, J. R., Bohan, D.A. \& Symondson, W.O.C. (2011) Multiplex reactions for the molecular detection of predation on pest and non-pest invertebrates in agroecosystems. Molecular Ecology Resources 11, 370-373.
Kruse, P.D., Toft, S. \& Sunderland, K.D. (2008) Temperature and prey capture: opposite relationships in two predator taxa. Ecological Entomology 33, 305-312.

Kuusk, A.K. \& Agustí, N. (2008) Group-specific primers for DNA-based detection of springtails (Hexapoda: Collembola) within predator gut contents. Molecular Ecology Resources 8, 678-681.

Minitab Inc. (2008) Minitab Statistical Software, Release 15. Available online at http://www.minitab.com (accessed September 2011).

Pons, J. (2006) DNA-based identification of preys from nondestructive, total DNA extractions of predators using arthropod universal primers. Molecular Ecology Notes 6, 623-626.

Read, D.S. (2007) Molecular analysis of subterranean detritivore food webs. PhD thesis, University of Cardiff, Cardiff, UK.

Remén, C., Krüger, M. \& Cassel-Lundhagen, A. (2010) Successful analysis of gut contents in fungal-feeding oribatid mites by combining body-surface washing and PCR. Soil Biology and Biochemistry 42, 1952-1957.

Sheppard, S.K., Bell, J., Sunderland, K.D., Fenlon, J., Skervin, D. \& Symondson, W.O.C. (2005) Detection of secondary predation by PCR analyses of the gut contents of invertebrate generalist predators. Molecular Ecology 14, $4461-4468$.

Sunderland, K.D., Powell, W. \& Symondson, W.O.C. (2005) Populations and communities. pp. 299-434 in Jervis, M.A. (Ed.) Insects as Natural Enemies: A Practical Perspective. Berlin, Germany, Springer.

Symondson, W.O.C. (2002) Molecular identification of prey in predator diets. Molecular Ecology 11, 627-641.

Virant-Doberlet, M., King, R.A., Polajnar, J. \& Symondson, W. O.C. (2011) Molecular diagnostics reveal spiders that exploit prey vibrational signals used in sexual communication. Molecular Ecology 20, 2204-2216.

von Berg, K., Traugott, M., Symondson, W.O.C. \& Scheu, S. (2008) The effects of temperature on detection of prey DNA in two species of carabid beetle. Bulletin of Entomological Research 98, 263-269.

Wheater, C.P., Bell, J.R. \& Cook, P.A. (2011) Practical Field Ecology: A Project Guide. London, UK, Wiley-Blackwell.

Wootton, J.T. \& Emmerson, M. (2005) Measurement of interaction strength in nature. Annual Review of Ecology Evolution and Systematics 36, 419-444. 